\title{
Therapeutics potential of Ocimum basilicum following mercury chloride-induced hepatotoxicity in rats (Rattus norvegicus)
}

\author{
Sunday A. Adelakun ${ }^{1}, *$, Olusegun D. Omotoso $^{2}$ and Grace T. \\ Akingbade $^{1}$
}

${ }^{1}$ Department of Human Anatomy. School of Health and Health Technology. Federal University of Technology. Akure. Ondo State. Nigeria. E-mail: saadelakun@futa.edu.ng.

${ }^{2}$ Department of Anatomy, Faculty of Basic Medical Sciences, Kogi State University Anyigba, Kogi State, Nigeria.

\begin{abstract}
Globally mercury $(\mathrm{Hg})$ has been reported as one of heavy metal of known toxicity, noted for inducing public health disasters. Present study examines the therapeutics potentials of Ocimum basilicum on mercury chloride $\left(\mathrm{HgCl}_{2}\right)$ induced hepatotoxicity in Wistar rats. Thirty adult Wistar rats randomly divided into six groups (A-F) of five rats each. Group A served as control was given $2 \mathrm{~mL} /$ day of distilled water, Group B, C, D, E and $\mathrm{F}$ received $500 \mathrm{mg} / \mathrm{kg}$ body weight (bwt) of $O$. basilicum extract, $20 \mathrm{mg} / \mathrm{kg} / \mathrm{bwt}$ of $\mathrm{HgCl}_{2}, 40 \mathrm{mg} / \mathrm{kg}$ bwt of $\mathrm{HgCl}_{2}, 20$ $\mathrm{mg} / \mathrm{kg}$ bwt of $\mathrm{HgCl}_{2}$ and $500 \mathrm{mg} / \mathrm{kg}$ bwt $O$. basilicum leave extract, $40 \mathrm{mg} / \mathrm{kg}$ bwt and $500 \mathrm{mg} / \mathrm{kg}$ bwt $O$. basilicum administered daily by gastric gavage, for 21 consecutive days. The gross anatomical parameters of the liver and liver histology were assessed. Liver oxidative stress was evaluated by liver superoxide dismutase (SOD), catalase (CAT), glutathione peroxidase (GPx), reduced glutathione (GSH) and malondialdehyde (MDA) assays. The activities of the biomarker enzymes of the liver (alanine transaminase, aspartate transaminase and alkaline phosphatase were assayed). Histological profiles of the liver revealed derangement of the liver cytoarchitecture following consumption of mercury chloride and a marked improvement was observed after $O$. basilicum administration. Similarly, 0 . basilicum improved the reduction of antioxidant parameters (SOD, CAT, GPx and GSH) and the increased MDA caused by mercury chloride consumption. $O$. basilicum thus proffer protection against free radical mediated oxidative stress in mercury chloride-induced hepatotoxicity in rats.
\end{abstract}

Keywords: Histology; Ocimum basilicum; Mercury chloride; Oxidative stress; Rat; Liver.
Received

October 30, 2018

Accepted

December 23, 2018

Released

December 31, 2018

Full Text Article

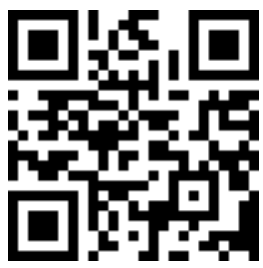

ORCID

(D) 0000-0002-8328-3119 Sunday A. Adelakun

(1) 0000-0001-7962-3363 Olusegun D. Omotoso

(D) 0000-0002-7899-5138

Grace T. Akingbade 


\section{Introduction}

There is a growing problem of worldwide contamination of the environment with mercury, the fate and behavior of mercury in the environment depends on its chemical form (Rice et al., 2014). Inorganic mercury compounds enter water bodies by different ways and undergo a process of methylation (Gilmour and Henry, 1991). Mercury poisoning result from inhalation, ingestion, or absorption through the skin and may be highly toxic and corrosive once absorbed into blood stream (Khan et al., 2004). High exposures to inorganic mercury may result in damage to the gastrointestinal tract, the nervous system, and the kidneys (USEPA, 2018). Many populations worldwide have been exposed to doses of mercury through the consumption of fishes and sea foods (Valey et al., 1980; WHO, 2003). The most famous case of contamination with organic mercury is the Minamata case in the 1950/1960s in Japan (Popescu, 1978; Tan et al., 2009). People who consumed food mainly fish, contaminated with methyl mercury presented several health problems, especially children exposed to the metal in utero (Ekino et al., 2007). Liver is a target organ for the accumulation of cadmium and mercury (Yannai and Sachs, 1993). Mercury is a prevalence environmental and industrial pollutant, which induces severe alterations in the tissues of both animals and men (Lund et al., 1983; Stacey and Kappus, 1982). It is highly toxic metal, results in a variety of adverse health effects including neurological, renal, respiratory, immune, dermatologic, reproductive and developmental sequels (Risher and Amler, 2005). Mercury recycles through the entero-hepatic system in adults and is excreted primarily in the faeces (Dalia, 2010).

Ocimum basilicum L. is a medicinal plant which has received a great deal of attention over the past few decades around the world, It belongs to the Lamiaceae Family of floral plants usually producing white-purple flowers (Daneshian et al., 2009). It is commonly known as sweet basil (Omidbaig, 2005). Basil is one of the species used for the commercial seasoning and it is commonly known that the presence of essential oils and their composition determine the specific aroma of plants and the flavour of the condiments (Marotti et al., 1996).

Many species of aromatic plants belonging to the Lamiaceae Family grow wild in the Mediterranean Basin (Akgül, 1989; Sanda et al., 1998; Martins et al., 1999). Hot tea of basil plant leaves is good for treating nausea, dysentery and flatulence. Externally it can be used for different skin infections such as treatment of acne, snake bites and insect stings. In addition to these, basil has been used as a remedy for an enormous number of ailments, including cancer, convulsion, deafness, diarrhea, epilepsy, insanity, sore throat, toothaches, and whooping cough (Khatri et al., 1995).

$O$. basilicum is being utilized as a source of essential oils mainly in industries, perfumery, dental, oral products and traditional ritual (Pino et al., 1996; Saira et al., 2014). Recent scientific research has investigated the health benefits associated with Ocimum basilicum essential oils. Studies reveal the anti-viral, anti-microbial, antioxidant, and anti-cancer properties of the oils; further research is underway (Chiang et al., 2005; Bozin et al., 2006).

Liver is the largest gland in our body, the vital metabolic organ which metabolizes various xenobiotics daily. In the process the organ is affected by various chemicals and toxins. Exposure to different organic and inorganic elements and compounds including several environmental toxins, pollutants and drugs can cause induction of generation of highly reactive substances such as reactive oxygen species (ROS) who in turn can bring about oxidative stress mediated cellular damages. Identification of a successful 
hepatoprotective agent without any cytotoxic side effect will be very useful for treating hepatic diseases and protect this vital organ (Gnanaprakash et al., 2010).

The present study demonstrates the therapeutics potentials of O. basilicum on mercury chloride induced hepatotoxicity in Wistar rats.

\section{Materials and methods}

\section{Ocimum basilicum}

The plant material was collected from research Farm Federal University of Technology, Akure, Nigeria, and $O$. basilicum leaves were identified by Dr. K. D Ileke in the Department of Biological Science, of Federal University of Technology, Akure, Nigeria.

\section{Preparation of extract}

Plant materials were air dried at room temperature and ground by using electronic blender model FS-343, Indian) to powdered form. $67 \mathrm{~g}$ of 0 . basilicum leaves powder was soaked in $1,000 \mathrm{~mL}$ of $95 \%$ ethanol for five days at room temperature. The mixture was mixed daily for regular infusion after five days the extract was filter by using Whatman filter paper No.1. The filtrate was dried using rotary evaporator at $60{ }^{\circ} \mathrm{C}$. The dried extract was stored in sterile glass bottles at $-20^{\circ} \mathrm{C}$ until use (Kandil et al., 1994).

\section{Animals and Diet}

30 adult Wistar rats obtained from a breeding stock maintained in the animal house of Department of Anatomy, School of Health and Health Technology, Federal University Of Technology, Akure, Ondo State, Nigeria.

The rats were fed with standard rat chow at a recommended dose of 100 $\mathrm{g} / \mathrm{kg}$ as advised by the International Centre of Diarrheal Disease Research, Bangladesh (ICDDR, B) daily, drinking water was supplied ad libitum and they were randomly divided into six groups (A-F) of five rats each in a separate room at a constant temperature $\left(22.0{ }^{\circ} \mathrm{C} \pm 1.0\right.$ ${ }^{\circ} \mathrm{C}$ ) under a $12 \mathrm{~h} \mathrm{light/dark} \mathrm{cycle.} \mathrm{Rats} \mathrm{in}$ Group A served as control was given $2 \mathrm{~mL} / \mathrm{kg} /$ day of distilled water, Group B received $O$. basillicum leave extract at $500 \mathrm{mg} / \mathrm{kg}$ bwt. Group C received $\mathrm{HgCl}_{2}$ at $20 \mathrm{mg} / \mathrm{kg}$ bwt. Group D received $\mathrm{HgCl}_{2}$ at $40 \mathrm{mg} / \mathrm{kg}$. Group E received $\mathrm{HgCl}_{2}$ at $20 \mathrm{mg} / \mathrm{kg}$ bwt and $O$. basillicum leave extract at $500 \mathrm{mg} / \mathrm{kg}$ bwt. Group F received $\mathrm{HgCl}_{2}$ at $40 \mathrm{mg} / \mathrm{kg}$ bwt, and $O$. basillicum leave extract at $500 \mathrm{mg} / \mathrm{kg}$ bwt, administered daily by gastric gavage, for 21 consecutive days.

All experimental investigations were done in compliance with humane animal as stated in the "Guide to the Care and Use of Laboratory Animals Resources" (NRC, 1985) and in accordance with the guideline and approval of Nigeria Medical Ethical Association for Accreditation of Laboratory Animal Care.

\section{extraction \\ Animal sacrificed and sample}

$12 \mathrm{~h}$ after the administration of the last mercury chloride and $O$. basillicum, the rats were at the time of sacrifice first weighed and then cervical dislocation was carried out following ethical humane animal euthanasia which was adopted with expertise cervical dislocation. The abdominal cavity of each rat was opened up through a midline thoracic incision to expose the liver. The liver was excised and weighed with an electronic analytical and precision balance. The liver of each animal was fixed in $10 \%$ formosaline for histological examination.

\section{Estimation of haematological parameters}

Blood was collected by means of Cardiac puncture and blood cell count was done using an auto-analyzer. Red blood cell count (RBC), mean corpuscular hemoglobin $(\mathrm{MCH})$, mean corpuscular hemoglobin concentration (MCHC), platelet count, white blood cell count (WBC), packed cell volume was analyzed 
and differential white blood cell count was done.

\section{Determination of serum} glucose, total protein, albumin levels and ALT, AST and ALP assay

The degree of liver damage was evaluated by ALT, AST and ALP in serum using a commercially available kit. Detailed procedures for the above measurements were performed according to the kit manufacturer's instructions.

\section{Determination of oxidative stress parameters \\ SOD activity in liver was} determined according to the method described by Marklund and Marklund (1974) and GSH-Px activity was determined by GSH-Px assay kit. Detailed procedures for the above measurements were performed according to the kits' protocol. CAT was assayed by the method described by Ferro et al. (2010). The non-enzymic GSH was analyzed by the method of Moron et al. (1979).

\section{contents}

\section{Determination of Liver MDA}

Lipid peroxidation was evaluated on the base of MDA level and MDA in liver was determined using the method described by Jain et al. (1989).

\section{Protein quantification}

Protein was measured by the method of Bradford (1976), using bovine serum albumin as the standard.

\section{tissues \\ Histological preparation of}

This was done as described by Omotoso et al. (2016). The liver was fixed in $10 \%$ formosaline to prevent autolysis. The liver was passed through ascending grades of alcohol $(70 \%, 80 \%$, $90 \%$ and absolute $100 \%$ ) to gradually remove its water contents. The sample was placed in xylene to remove the alcohol. This improves the refractive index of the tissue. The tissue was immersing in molten paraffin wax so that the holes left by the alcohol would be filled up. This gives the tissue support. The tissue is placed into an embedding mold which is filled with more paraffin wax and allowed to solidify. This is done in order to make the tissue compact for sectioning. The block is trimmed to remove the excess wax. The block of tissue was placed in a microtome and trimmed to expose the surface. The microtome was set to 3-5 micron and the tissue was sectioned. The sections were picked with forceps and placed in a water bath to float out and spread well. It was picked with a slide

Statistical analysis
Data were expressed as
Mean \pm SEM. Statistical differences
between the groups were evaluated by
one-way ANOVA, followed by Dunnets
comparison test to compare between
treated and control groups. Differences
yielding p < 0.05 were considered
statistically significant. All statistical
analysis of data was performed using
GraphPad Prism 5.0 for Windows
(GraphPad Software, San Diego,
California, USA).

\section{Result}

\section{Physical observation}

During the period of administration, the animals were given intimate observation throughout the period of experiment. During acclimatization, all animals appeared presumably normal with laid hairs and pinkish eyes with good feeding habit. The animals were observed to be using their forelimbs to scratch their mouth on mercury chloride administration, the animals got weakened which was observed as a result of reduction of their physical activities. There was decrease in body weight in the animals administered with mercury chloride only, especially after day 14 and 21 of treatment whereas there was increase in body weight in the control group. 


\section{Body weight}

The differences in body of animals subjected to different treatments were shows in Table 1. During the course of present investigations. It was observed that the body weight in control and $O$. basilicum treated group increased progressively, contrary, in $\mathrm{HgCl}_{2}$ treated rats, results revealed significant decreased in body weight gain as compared to the control.

Table 1. Shows mean body weights in control and treated rats.

\begin{tabular}{|l|c|c|c|c|c|c|}
\hline \multirow{2}{*}{ Period } & \multicolumn{7}{|c|}{ Treatment groups } \\
\cline { 2 - 7 } & Group A & Group B & Group C & Group D & Group E & Group F \\
\hline Day 1 & $160.0 \pm 4.472$ & $195.0 \pm 2.000^{*}$ & $200.0 \pm 2.010^{*}$ & $200.0 \pm 8.000^{*}$ & $200.0 \pm 12.65^{*}$ & $224.0 \pm 28.21^{*}$ \\
\hline Day 7 & $180.0 \pm 6.325$ & $217.5 \pm 4.787$ & $231.0 \pm 3.674^{*}$ & $223.0 \pm 6.782^{*}$ & $199.0 \pm 7.810^{*}$ & $234.0 \pm 19.90^{*}$ \\
\hline Day 14 & $186.0 \pm 4.000$ & $222.5 \pm 3.782^{*}$ & $228.0 \pm 9.138^{*}$ & $204.0 \pm 9.695^{*}$ & $206.0 \pm 6.000^{*}$ & $223.3 \pm 28.48^{*}$ \\
\hline Day 21 & $194.0 \pm 6.782$ & $227.5 \pm 4.787$ & $219.0 \pm 9.950$ & $184.0 \pm 10.68$ & $197.5 \pm 4.330$ & $221.7 \pm 29.20^{*}$ \\
\hline
\end{tabular}

Values are expressed as mean $\pm S D$ for $n=5 ;{ }^{*} p<0.05$, significantly dissimilar from control One-Way ANOVA. OB: Ocimum basillicum, bwt: body weight. A: (Control) Distilled water, B: (500 mg/kg bwt of OB), C: $\left(20 \mathrm{mg} / \mathrm{kg}\right.$ bwt of $\left.\mathrm{HgCl}_{2}\right), \mathrm{D}:\left(40 \mathrm{mg} / \mathrm{kg}\right.$ bwt of $\left.\mathrm{HgCl}_{2}\right), \mathrm{E}:(20 \mathrm{mg} / \mathrm{kg}$ bwt and $500 \mathrm{mg} / \mathrm{kg}$ bwt OB), F: (40 mg/kg bwt and $500 \mathrm{mg} / \mathrm{kg}$ bwt OB).

\section{weights \\ Absolute and relative liver \\ The difference in absolute and} relative liver weights of animals subjected to different treatments were shows in Table 2. During the course of present investigations, there was observed significant increase in absolute and relative liver weights of $\mathrm{HgCl}_{2}$ and $O$. basilicum treated group as compared to the control.

Table 2. Showing difference in absolute and relative liver weights in control and treated rats.

\begin{tabular}{|l|c|c|c|c|c|c|}
\hline \multirow{2}{*}{ Parameters } & \multicolumn{7}{|c|}{ Treatment groups } \\
\cline { 2 - 7 } & Group A & Group B & Group C & Group D & Group E & Group E \\
\hline $\begin{array}{l}\text { Absolute Liver } \\
\text { weight (g) }\end{array}$ & $4.32 \pm 0.10$ & $4.53 \pm 0.26^{*}$ & $4.51 \pm 0.15^{*}$ & $4.69 \pm 0.12^{*}$ & $4.79 \pm 0.17^{*}$ & $4.90 \pm 0.10^{*}$ \\
\hline $\begin{array}{l}\text { Relative Liver } \\
\text { weight (g/100 g } \\
\text { bwt) }\end{array}$ & $2.21 \pm 2.23$ & $2.32 \pm 0.13$ & $2.26 \pm 0.08$ & $2.35 \pm 1.5$ & $2.40 \pm 1.34$ & $2.19 \pm 0.35$ \\
\hline
\end{tabular}

Values are expressed as mean $\pm S D$ for $n=5$; ${ }^{*}<<0.05$, significantly dissimilar from control One-Way ANOVA. OB: Ocimum basillicum, bwt: body weight. A: (Control) Distilled water, B: (500 mg/kg bwt of OB), C: $\left(20 \mathrm{mg} / \mathrm{kg}\right.$ bwt of $\left.\mathrm{HgCl}_{2}\right), \mathrm{D}:\left(40 \mathrm{mg} / \mathrm{kg}\right.$ bwt of $\left.\mathrm{HgCl}_{2}\right), \mathrm{E}:(20 \mathrm{mg} / \mathrm{kg}$ bwt and $500 \mathrm{mg} / \mathrm{kg}$ bwt OB), F: (40 mg/kg bwt and $500 \mathrm{mg} / \mathrm{kg}$ bwt OB)

\section{Effects of treatments on serum biochemical Parameters \\ As showed in Table 3, the serum} levels of AST, ALT and ALP were significantly increased in the mercury chloride group compared to the control group, but the serum AST, ALT and ALP activities in mercury chloride and Ocimum basilicum group were significantly lower than that of the mercury chloride group. However, combined administration of 0 . basilicum 
with mercury chloride results in gradual recovery in AST, ALT and ALP activities as compared to the control group. The content of serum glucose of the mercury chloride treated group tented to be higher compared to the control. Albumin and protein levels in mercury chloride treated animals were decreased, but the co-administration of $O$. basilicum with mercury chloride has produced a recovery in the above mentioned biochemical variables.

Table 3. Shows difference in biochemical parameters in control and treated rats.

\begin{tabular}{|l|l|l|l|l|l|l|}
\hline \multirow{2}{*}{ Groups } & \multicolumn{7}{|c|}{ Parameters } & \multirow{2}{*}{\begin{tabular}{c} 
Total \\
\cline { 2 - 7 }
\end{tabular}} & \multicolumn{1}{|c|}{$\begin{array}{c}\text { Glucose } \\
\mathbf{m g} / \mathbf{d L})\end{array}$} & $\begin{array}{c}\text { protein } \\
\mathbf{( g / d L )}\end{array}$ & $\begin{array}{c}\text { Albumin } \\
\mathbf{( g / d L )}\end{array}$ & \multicolumn{1}{|c|}{ AST(U/L) } & ALT(U/L) & ALP (U/l) \\
\hline Group A & $77.59 \pm 7.92$ & $8.70 \pm 0.53$ & $5.90 \pm 0.38$ & $99.10 \pm 1.03$ & $25.82 \pm 0.73$ & $240.0 \pm 6.10$ \\
\hline Group B & $73.14 \pm 1.60$ & $9.04 \pm 0.42$ & $5.52 \pm 0.30$ & $122.70 \pm 1.5^{*}$ & $36.80 \pm 0.74^{*}$ & $230.4 \pm 1.75^{*}$ \\
\hline Group C & $95.49 \pm 3.09^{*}$ & $7.47 \pm 0.30^{*}$ & $4.52 \pm 0.32^{*}$ & $151.20 \pm 1.27^{*}$ & $61.89 \pm 0.72^{*}$ & $240.3 \pm 1.67$ \\
\hline Group D & $98.58 \pm 2.33^{*}$ & $8.45 \pm 0.40$ & $4.77 \pm 0.31^{*}$ & $153.30 \pm 1.07^{*}$ & $62.97 \pm 0.69^{*}$ & $244.6 \pm 1.24$ \\
\hline Group E & $82.16 \pm 4.05$ & $8.26 \pm 0.15$ & $5.67 \pm 0.35$ & $140.00 \pm 100^{*}$ & $59.94 \pm 0.71^{*}$ & $230.6 \pm 1.60^{*}$ \\
\hline Group F & $87.22 \pm 8.50^{*}$ & $8.45 \pm 0.26$ & $5.44 \pm 0.43$ & $142.70 \pm 0.83^{*}$ & $60.50 \pm 0.72^{*}$ & $232.8 \pm 2.27^{*}$ \\
\hline
\end{tabular}

Values are expressed as mean \pm SD for $n=5 ;{ }^{*} p<0.05$, significantly dissimilar from control One-Way ANOVA. OB: Ocimum basillicum, bwt: body weight. A: (Control) Distilled water, B: (500 mg/kg bwt of $\mathrm{OB}$ ), C: (20 mg/kg bwt of $\left.\mathrm{HgCl}_{2}\right)$, D: $\left(40 \mathrm{mg} / \mathrm{kg}\right.$ bwt of $\left.\mathrm{HgCl}_{2}\right)$, E: $(20 \mathrm{mg} / \mathrm{kg}$ bwt and $500 \mathrm{mg} / \mathrm{kg}$ bwt OB), F: (40 mg/kg bwt and $500 \mathrm{mg} / \mathrm{kg}$ bwt OB).

\section{Antioxidant levels (CAT, SOD, GSH, GP ) and MDA levels}

Showed in Table 4, the MDA levels in group $C$ and $D$ increased compared with the control group A but decreased in group B, E and F compared to mercury chloride group (C and D). The anti-oxidant levels (CAT, SOD, GSH and GPx ) decreased significantly in mercury chloride group (C and D) $\left({ }^{*} \mathrm{P}<0.05\right)$ compared to the control group but the CAT, SOD, GSH and GPx level group B, E and $\mathrm{F}$ decreases $\left({ }^{*} \mathrm{P}<0.05\right)$ compared to the control group.

Table 4. Shows antioxidant and lipid peroxidation levels in liver of control and treated rats.

\begin{tabular}{|l|c|c|c|c|c|}
\hline \multirow{2}{*}{ Groups } & \multicolumn{5}{|c|}{ Parameters } \\
\cline { 2 - 6 } & $\begin{array}{c}\text { MDA } \\
\text { (nmol/mg } \\
\text { protein) }\end{array}$ & $\begin{array}{c}\text { CAT } \\
(\boldsymbol{\mu} / \mathbf{m g} \\
\text { protein) }\end{array}$ & $\begin{array}{c}\text { SOD } \\
(\boldsymbol{\mu} / \mathbf{m g} \\
\text { protein) }\end{array}$ & $\begin{array}{c}\text { GST } \\
\text { (nmol/mg } \\
\text { protein) }\end{array}$ & $\begin{array}{c}\text { GPx } \\
\text { (nmol/mg } \\
\text { protein) }\end{array}$ \\
\hline Group A & $8.76 \pm 0.21$ & $21.70 \pm 1.21$ & $14.86 \pm 0.77$ & $9.48 \pm 0.47$ & $6.36 \pm 0.40$ \\
\hline Group B & $7.72 \pm 0.24^{*}$ & $19.54 \pm 0.40$ & $14.18 \pm 0.68$ & $8.54 \pm 0.40^{*}$ & $4.14 \pm 0.23^{*}$ \\
\hline Group C & $11.04 \pm 0.50^{*}$ & $13.58 \pm 0.66$ & $6.30 \pm 0.80^{*}$ & $5.62 \pm 0.36^{*}$ & $2.32 \pm 0.41^{*}$ \\
\hline Group D & $12.20 \pm 0.60^{*}$ & $14.82 \pm 0.73$ & $7.50 \pm 0.46^{*}$ & $6.28 \pm 0.67^{*}$ & $2.66 \pm 0.42^{*}$ \\
\hline Group E & $6.70 \pm 0.45^{*}$ & $16.94 \pm 0.36$ & $11.74 \pm 0.57^{*}$ & $7.80 \pm 0.46^{*}$ & $3.78 \pm 0.38^{*}$ \\
\hline Group F & $8.60 \pm 0.45$ & $19.02 \pm 0.58$ & $14.30 \pm 0.56$ & $8.40 \pm 0.51^{*}$ & $3.64 \pm 0.66^{*}$ \\
\hline
\end{tabular}

Values are expressed as mean \pm SD for $n=5$; $* \mathrm{p}<0.05$, significantly dissimilar from control One-Way ANOVA. OB: Ocimum basillicum, bwt: body weight. A: (Control) Distilled water, B: (500 mg/kg bwt of OB), C: (20 mg/kg bwt of $\mathrm{HgCl}_{2}$ ), D: (40 mg/kg bwt of $\left.\mathrm{HgCl}_{2}\right)$, E: $(20 \mathrm{mg} / \mathrm{kg}$ bwt and $500 \mathrm{mg} / \mathrm{kg}$ bwt OB), F: (40 mg/kg bwt and $500 \mathrm{mg} / \mathrm{kg}$ bwt OB). 


\section{Hematological parameters}

As showed in Table 5 the mean value of hematological parameters of group $\mathrm{C}$ and $\mathrm{D}$ decrease when compared to group A indicating the toxic effect of mercury chloride. Mean value of Group B, $\mathrm{E}$ and $\mathrm{F}$ compared with Group $\mathrm{C}$ and $\mathrm{D}$ indicating the effect of $O$. basilicum and co-administration of mercury chloride and $O$. basilicum.

Table 5. Shows Hematological Indices in control and treated rats.

\begin{tabular}{|l|c|c|c|c|c|}
\hline \multirow{2}{*}{ Groups } & \multicolumn{5}{|c|}{ Parameters } \\
\cline { 2 - 6 } & PCV (I/L) & Hb (g/L) & Neutrophl & Lymphocyt & Eosinophil \\
\hline Group A & $0.76 \pm 0.04$ & $18.07 \pm 0.72$ & $35.5 \pm 1.40$ & $83.28 \pm 1.07$ & $3.01 \pm 0.84$ \\
\hline Group B & $0.76 \pm 0.02$ & $15.41 \pm 0.87^{*}$ & $32.24 \pm 1.09^{*}$ & $84.66 \pm 1.00$ & $3.91 \pm 0.50$ \\
\hline Group C & $0.78 \pm 0.02$ & $17.90 \pm 0.88^{*}$ & $36.40 \pm 0.65$ & $80.89 \pm 1.00^{*}$ & $3.65 \pm 0.54$ \\
\hline Group D & $0.77 \pm 0.01$ & $16.33 \pm 0.89^{*}$ & $36.31 \pm 1.42$ & $79.32 \pm 1.02^{*}$ & $4.22 \pm 0.87$ \\
\hline Group E & $0.74 \pm 0.02$ & $16.33 \pm 0.93^{*}$ & $35.74 \pm 1.31$ & $78.82 \pm 1.71^{*}$ & $3.70 \pm 0.57$ \\
\hline Group F & $0.75 \pm 0.02$ & $16.33 \pm 0.93^{*}$ & $33.77 \pm 1.02^{*}$ & $85.44 \pm 0.87^{*}$ & $3.35 \pm 0.80$ \\
\hline
\end{tabular}

Values are expressed as mean \pm SD for $n=5 ;{ }^{*} p<0.05$, significantly dissimilar from control One-Way ANOVA. OB: Ocimum basillicum, bwt: body weight, PCV: Packed cell volume, Hb: Hemoglobin concentration. A: (Control) Distilled water, B: (500 mg/kg bwt of OB), C: (20 mg/kg bwt of $\left.\mathrm{HgCl}_{2}\right)$, D: $\left(40 \mathrm{mg} / \mathrm{kg}\right.$ bwt of $\mathrm{HgCl}_{2}$ ), E: (20 mg/kg bwt and $500 \mathrm{mg} / \mathrm{kg}$ bwt OB), F: (40 mg/kg bwt and 500 $\mathrm{mg} / \mathrm{kg}$ bwt OB).

\section{Liver histology}

Cross section of the livers of animals after the study showed that Group A had a normal histoarchitecture of the liver with central vein, hepatocytes, sinusoid and kupffer cells. Group B showed intact hepatocyte cells, central vein and sinusoid however, Groups C and D showed mononuclear cell infiltration, congestion of central vein and diffused necrosis of hepatocytes. Group E showed restoration in the hepatocyte, mild congestion of the cytoplasm, absence of centrilobular necrosis with nearly visible central vein. The result from Group $F$ showed restoration in the hepatocyte, mild congestion of the cytoplasm, absence of centrilobular necrosis with nearly visible central vein (Figure 1).

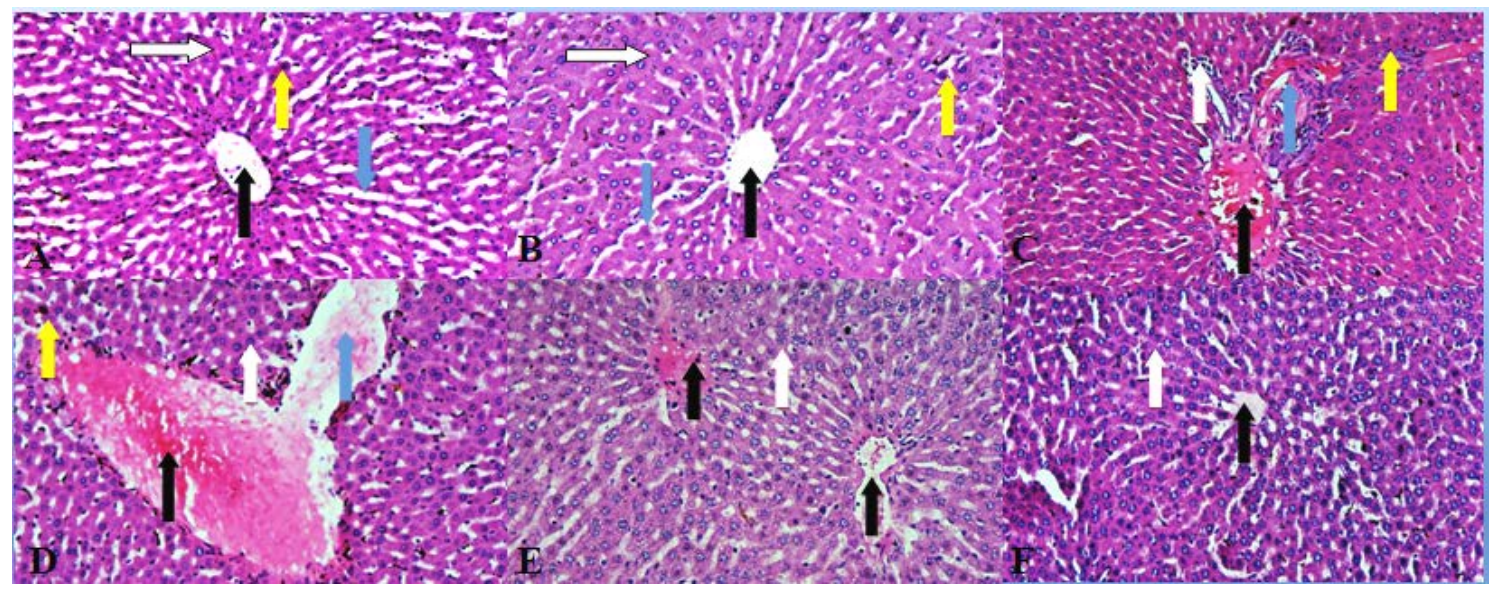

Figure.1. Photomicrograph of section of Liver Group A control and group B showing intact hypatocyte cells (white arrow), CV: central vein (black arrow), S: sinusoid (blue arrow) and kupffer cells (K yellow arrow). Group (C-D) with cellular necrosis (CN white arrow), central vein (CV black arrow), enlarged sinusoids (S blue arrow), mononuclear cellular infiltration (MN yellow arrow). Group (E-F) showing restoration in the heptocyte (white arrow), mild congestion of the cytoplasm, absence of centrilobular necrosis with nearly visible central vein (black arrow). H\&E x400. 


\section{Discussion}

The accumulation of noticeable amount of mercury in liver tissue resulted in induction of oxidative stress response in the liver. Mercury is a common environmental and occupational toxic heavy metal, which is known to have direct and indirect effects on biological systems and cells (Hesse, 2007; Jaishankar et al., 2011). One of the ways that mercury exerts its toxic effects is through oxidative stress that may be an important contributor to the negative pathogenesis observed after mercury chloride exposure (Valera et al., 2008; ATDRS, 2011). Oxidative stress can be defined as a situation of an imbalance toward the pro-oxidant side of the prooxidant/antioxidant balance (Mitra et al., 2012).

O. basilicum is a medicinal plant which has received a great deal of attention over the past few decades around the world. It belongs to the Lamiaceae Family of floral plants usually producing white-purple flowers (Keita et al., 2000; Daneshian et al., 2009).

The present study revealed that mercury chloride intoxication causes significant increased in lipid peroxidation and glucose levels, significant decreased in the serum albumin and total protein. The activities of aspartate aminotransferase (ALT), alanine aminotransferase (AST) and ALP in the serum of rats are tested as indicator for hepatic function (ElMaraghy et al., 2001; Kumar et al., 2005). In our study, the activities of ALT, AST and ALP in the serum of mercuric chloride exposed rats were significantly increased indicating mercury related injury to the liver. This is in accordance as reported by Brzóska et al. (2003), Pari and Murugavel (2005) also the increased in these enzymes may be due to cellular necrosis of hepatocytes, which increases in the permeability of cell resulting in release of transaminases and ALP in the blood stream (Vandenberghe, 1995; Rana et al., 1996). This confirms our earlier reports on histological alterations in liver induced by mercury intoxication which is in accordance as reported by (Sharma et al., 2000; 2002) but the serum AST, ALT and ALP activities in the mercuric chloride and $O$. basilicum group were significantly lower than in the mercury chloride group. However, combined administration of $O$. basilicum with mercury chloride results in gradual recovery in AST, ALT and ALP activities as compared to the control group. The content of serum glucose of the mercury chloride treated group tented to be higher compared to the control. Albumin and protein levels in mercuric chloride treated animals were decreased, but the co-administration of $O$. basilicum with mercury chloride has produced a recovery in the above mentioned biochemical variables.

The reduction in PCV and $\mathrm{Hb}$ in this study revealed microcytic hypochromic anemia. This observation was consistent with an earlier observation of others on genotoxic potential of mercuric chloride and different anti-oxidants alone or in combined form in the liver and other tissues (Wang et al., 2007; Burger et al., 2011; Cordeiro Júnior et al., 2012). Coadministration of mercuric chloride with O. basilicum in the present study resulted in ameliorative effects on haematobiochemical parameters. However, the overall mean value of the group treated with $O$. basilicum tend to move towards normal, indicating the recuperative effect of this anti-oxidant against mercury toxicity as reported by (Ibegbu et al., 2014).

In addition, the antioxidant enzymes and lipid peroxidation levels can be used to predict the degree of mercuric chloride induced liver damage. Antioxidants enzymes such as SOD, CAT, GSH and GPx dependently act in the metabolic pathways that involve free radicals. Therefore, SOD, CAT, GSH and GPx levels decreased in liver due to toxic effects of mercury chloride on liver functions but the administration of $O$. 
basilicum can counter the impact of mercury chloride on liver cells thereby blocking the decreased antioxidants levels. Since it was proved that the significance of GSH in the detoxification of chemically reactive metabolite in drug induced toxicity after decreased in GSH (James et al., 1982; Saalu et al., 2012) then we can conclude that increased oxidation and decreased synthesis of GSH causes decreased in GSH levels. Therefore, increased in antioxidant enzyme activities levels (SOD, CAT, GSH and GPx) after $O$. basilicum extracts administration might contribute to the ameliorating effects of oxidative stress. MDA is a known biomarker of lipid peroxidation and oxidative stress, the increased in MDA level shows the toxic effects of mercury chloride on liver (Trush et al., 1982) but the counter actions of 0 . basilicum in reducing MDA level suggest the potential characteristics of $O$. basilicum in the restoration of damaged liver tissues following exposure to mercury chloride. Therefore, the antioxidant potential improved the liver functions by promoting antioxidant enzyme activities of $O$. basilicum. Also during the period of administration, the animals were given intimate observation throughout the period of experiment and during acclimatization, all animals appeared presumably normal with laid hairs and pinkish eyes with good feeding habit. The animals were observed to be using their forelimbs to scratch their mouth on mercury chloride administration, the animals got weakened which was observed as a result of reduction of their physical activities. There was decreased in body weight in the animals administered with mercury chloride only, especially after day 14 and 21 of treatment whereas there was increased in body weight in the Control group these is in accordance as reported by Ibegbu et al. (2014).

Furthermore, histological evaluation following mercury chloride consumption suggests inflammation of the hepatocyte, hepatocytic vacuolation and congested sinusoids. However, $O$. basilicum extracts treated group shows fewer areas of congestion, wider sinusoidal spaces and presence of binucleated cells indicating proliferation and regeneration which are in conformity with previous study Ibegbu et al. (2014) and Youcef et al. (2013) reported effects of ascorbic acid on mercury-induced changes on the liver in adult Wistar rats and amelioration of mercury chloride toxicity on rat liver with argan oil and sodium selenite supplements.

There was an observable improvement in the microscopic appearance of the liver after 0 . basilicum administration showing restoration in the hepatocyte, mild congestion of the cytoplasm, absence of centrilobular necrosis with nearly visible central vein. Since 0 . basilicum has antioxidant components that can alter the damage done following exposure to mercury chloride, we can therefore conclude from our findings that $O$. basilicum tentatively decreased the effects of mercury chloride on the liver of rats.

\section{Conclusion}

It may be concluded that combined administration of 0 . basilicum has a preventive and protective effect on mercury chloride induced oxidative stress. It protects from $\mathrm{HgCl}_{2}$ induced hepatic dysfunction and executes its modulatory role in mercury chloride induced free radical production.

\section{Conflicts of interest}

Authors declare that they have no conflict of interests.

\section{References}

Akgül, A. Volatile oil composition of sweet basil (Ocimum basilicum L.) cultivating in Turkey. Molecular Nutrition \& Food Research, v. 33, p. 87-88, 1989. https://doi.org/10.1002/food.19890330129 
ATSDR - Agency for Toxic Substances and Disease Registration. Draft technology profile for mercury. Atlanta, Georgia, USA: US department of health and human services, 2011.

Bozin, B. N.; Mimica-Dukic, N. S.; Anackov, G. Characterization of the volatile composition of essential oils of some Lamiaceae species and the antimicrobial and antioxidant activities of the entire oils. Journal of Agricutural and Food Chemistry, v. 54, p. 1822-1828, 2006. https://doi.org/10.1021/ jf051922u

Bradford, M. A. Rapid and sensitive method for the quantities of microgram quantities of protein utilizing the principale of protein-dye binding. Analytical Biochemistry, v. 72, n. $1 / 2$, p. $248-254$, 1976. https://doi.org/ 10.1016/0003-2697(76)90527-3

Brzóska, M. M.; Moniuszko-Jakoniuk, J.; PiłatMarcinkiewicz, B.; Sawicki, B. Liver and kidney function and histology in rats exposed to cadmium and ethanol. Alcohol and Alcoholism, v.38, no. 1, p. 2-10, 2003.

Burger, J.; Jeitner, C.; Gochfeld, M. Locational differences in mercury and selenium levels in 19 species of saltwater fish from New Jersey. Journal of Toxicology and Environmental Health, Part A, v. 74, p.863-874, 2011. https://doi.org/10.1080/15287394.2011.57 0231

Chiang, L.-C.; Ng, L.-T.; Cheng, P.-W.; Chiang, W.; Lin, C.-C. Antiviral activities of extracts and selected pure constituents of Ocimum basilicum. Clincal and Experimental Pharmacology and Physiology, v. 32, p. 811-816, 2005. https://doi.org/10.1111/ j.1440-1681.2005.04270.x

Cordeiro Júnior, Q.; Faria, M. A. M.; Fráguas Júnior, R. Depression, insomnia, and memory loss in a patient with chronic intoxication by inorganic mercury. The Journal of Neuropsychiatry and Clinical Neuroscience, $\quad$ v. 1, p. 191-205, 2012. https://doi.org/10.1176/jnp.15.4.457

Dalia, D. M. E.-N. Effect of using pectin on lead toxicity. The Journal of American Science, v. 6, p. 112-130, 2010.

Daneshian, A. B.; Gurbuz, B. C.; Ipek, A. Chemical components of essential oils from Basil (Ocimum basilium L.) grown at different nitrogen levels. International Journal of Natural and Engineering Sciences, v. 3, p. 8-13, 2009.
Ekino, S.; Susa, M.; Ninomiya, T.; Imamura, V.; Kitamura, T. M. Minamata disease revisited: An update on the acute and chronic manifestations of methyl mercury poisining. Journal of Neurological Sciences, v. 26, p. 131-144, 2007. https://doi.org/10.1016/ j.jns.2007.06.036

El-Maraghy, S. A.; Gad, M. Z.; Fahim, A. T.; Hamdy, M. A. Effect of cadmium and aluminum in take on the antioxidant status and lipid peroxidation in rat tissues. Journal of Biochemical and Molecular Toxicology, v. 15 , p. 207-214, 2001. https://doi.org/ $10.1002 / j b t .18$

Ferro, C. D. O.; Chagas, V. L.; Oliveira, M. F.; Oliveira, P. L.; Schanaider, A. Atividade da catalase no pulmão, rim e intestino delgado não isquemiado de ratos após reperfusão intestinal. Revista do Colégio Brasileiro de Cirurgiões, v. 37, p. 31-38, 2010. https://doi.org/10.1590/S0100-699120 10000100008

Gilmour, C.C.; Henry, E. A. Mercury methylation in aquatic systems affected by acid deposition. Environmental Pollution, v. 71, p.131-169, 1991. https://doi.org/ 10.1016/0269-7491(91)90031-Q

Gnanaprakash, K.; Madhusudhana, C. C.; Ramkanth, S.; Alagusundaram, M.; Tiruvengadarajan, V.S.; Angala, P.S.; Mohamed Saleem, T.S. Aqueous extract of Flacourtia indica prevents carbon tetrachloride induced hepatotoxicity in rat. International Journal of Pharmacological and Pharmaceutical Sciences, v. 6, p. 51-55, 2010.

Hesse, R. W., Jr. Jewelry making through History: An encyclopedia. Westport: Greenwood Publishing, 2007.

Ibegbu, A. O.; Ayuba, M.; Animoku, A.; Brosu, D.; Adamu, S. A.; Akpulu, P.; Hamman, W. O.; Umana, U. E.; Musa, S. A. Effect of ascorbic acid on mercury-induced changes on the liver in adult Wistar rats. OSR Journal of Dental and Medical Sciences, v. 13, p. 10-16, 2014. https://doi.org/10.9790/0853-131021016

Jain, S. K.; McVie, R.; Duett, J.; Herbst, J. J. Erythrocyte membrane lipid peroxidation and glycosylated hemoglobin in diabetes. Diabetes, v. 38, no. 12, p.1539-1543, 1989. https://doi.org/10.2337/diab.38.12.1539

Jaishankar, M.; Tseten, T.; Anbalagan, N.; Mathew, B. B.; Beeregowda, K. N. Toxicity, mechanism and health effects of some heavy 
metals. Toxicology, v. 7, no. 2, p. 60-72, 2014. https://doi.org/10.2478/intox-2014-0009

James, R. C.; Goodman, D. R.; Harbison, R. D. Hepatic glutathione and hepatotoxicity: Changes induced by selected narcotics. The Journal of Pharmacology and Experimental Therapeutics, v. 221, p. 708-714, 1982.

Kandil, O.; Radwan, N. M.; Hassan, A. B.; Amer, A. M.; El-Banna, H. A.; Amer, W. M. Extracts and fractions of Thymus capitatus exhibit antimicrobial activities. Journal of Ethnopharmacology, v. 44, p. 19-24, 1994. https://doi.org/10.1016/0378-8741(94) 90094-9

Keita, S. M.; Vincent, C.; Schmit, J. P.; Belanger, A. Essential oil composition of Ocimum basilicum L., O. gratissimum L. and $O$. suave L. in the Republic of Guinea. Flavour and Fragrance Journal, v. 15, p. 339-3341, 2000. https://doi.org/10.1002/1099-1026(200 009/10)15:5<339::AID-FFJ922>3.0.CO;2-H

Khatri, M.; Nasir, M.K.; Saleem, R.; Noor, F. Evaluation of Pakistani sweet basil oil for commercial exploitation. Pakistan Journal of Science \& Industrial Research, v. 38, p. 281-282, 1995.

Kumar, M.; Sharma, M. K.; Kumar, A. Spirulina fusiformis: A food supplement against mercury induced hepatic toxicity. Journal of Health Science, v. 51, no. 4, p. 424-430, 2005. https://doi.org/10.1248/jhs.51.424

Lund, B. O.; Miller, D.M.; Woods, J. S. Studies on $\mathrm{Hg}(\mathrm{II})$-induced $\mathrm{H}_{2} \mathrm{O}_{2}$ formation and oxidative stress in vivo and in vitro in rat kidney mitochondria. Biochemical Pharmacology, v. 45 , no. 10, p. 2017-2024, 1993. https://doi.org/10.1016/0006-2952 (93)90012

Marklund, S.; Marklund, G. Involvement of the superoxide anion radical in the autoxidation of pyrogallol and a convenient assay for superoxide dismutase. The FEBS Journal, v. 47, p. 469-474, 1974. https://doi.org/10.1111/j.1432-1033.1974. tb03714.x

Marotti, M.; Piccaglia, R.; Giovanelli E. Differences in essential oil composition of basil (Ocimum basilicum L.) Italian cultivars related to morphological characteristics. Journal of Agricultural and Food Chememistry, v. 14, p. 3926-3929, 1996. https://doi.org/10.1021/jf9601067

Martins, A. P.; Salgueiro, L. R.; Vila. R.; Tomi, F.; Cañigueral, S.; Casanova, J.; Cunha, A. P.;
Adzet, T. Composition of the essential oils of Ocimum canum, $O$. gratissimum and $O$. minimum. Planta Medica, v. 65, p. 187-189, $1999 . \quad$ https://doi.org/10.1055/s-2006960465

Mitra, E.; Ghosh, A. K.; Ghosh, D.; Mukherjee, D.; Chattopadhyay, A.; Dutta. S.; Pattari, S. K.; Bandyopadhyaya, D. Protective effect of aqueous curry leaf (Murraya koenigii) extract against cadmium-induced oxidative stress in rat heart. Food and Chemical Toxicology, v. 50, p. $1340-1353,2012$. https://doi.org/ 10.1016/j.fct.2012.01.048

Moron, M. S.; Depierre, J. W.; Mannervik, B. Levels of glutathione, glutathione reductase and glutathione S-transferase activities in rat lung and liver. Biochimica et Biophysica Acta (BBA) - General Subjects, v. 582, no.1, p. 67-78, 1979. https://doi.org/10.1016/ 0304-4165(79)90289-7

NRC - National Research Council. Guide to the care and use of laboratory animal resources. Washington, DC: National Research Council, 1985.

Omidbaig, R. Production and processing of medicinal plants. Tehran: Astane Quds Publication, 2005. v. 2.

Omotoso, O. D.; Adelakun, S. A.; Yusuf, U. A.; Adeleye, 0. 0.; Adeyinka, 0. 0. Assessment of the effects of Moringa oleifera oil, Anacardium occidentale oil and vitamin $\mathrm{C}$ and $E$ on the reticular fibres of cadmium-induced liver damage in Wistar rats. Journal of Advances in Medical and Pharmaceutical Sciences, v. 8, p. 1-8, 2016. https://doi.org/ 10.9734/JAMPS/2016/24239

Pari, L.; Murugavel, P. Role of diallyl tetrasulfide in ameliorating the cadmium induced biochemical changes in rats. Environmental Toxicology and Pharmacology, v. 20, p. 493-500, 2005. https://doi.org/10.1016/j.etap.2005.05.009

Pino, J.A.; Rosado, A.; Fuentes, V. Composition of the essential oil from the leaves and flowers of Ocimum gratissimum L. grown in Cuba. Journal of Essential Oil Research, v. 8, p. 139-141, 1996. https://doi.org/10.1080/10412905.1996.97 00581

Popescu, H. I. Poisoning with alkylmercury compounds. British Medical Journal, v. 1, no. 6123 , p. $1347,1978$.

Rana, S. V.; Singh, R.; Verma, S. Protective effects of few antioxidants on liver function in rats treated with cadmium and mercury. 
Indian Journal of Experimental Biology, v. 34, p. 177-179, 1996.

Riaz, M.; Khalid, M. R.; Hanif, M.; Chaudhary, F. M. Extraction and GC/MS analysis of the essential oil of Ocimum basilicum (Comoro). Pakistan Journal of Science and Industrial Research, v. 37, p. 362-364, 1994.

Rice, K. M.; Walker, Jr, E. M.; Wu, M.; Gillette, C.; Blough, E. R. Environmental mercury and its toxic effects. Journal of Preventive Medicine and Public Health, v. 47, no. 2, p. 74-83, 2014. https://doi.org/10.3961/ jpmph.2014.47.2.74

Risher, J. F.; Amler, S. N. Mercury exposure: Evaluation and intervention, the inappropriate use of chelating agents in diagnosis and treatment of putative mercury poisoning. Neurotoxicology, v. 26, p. 691699, 2005. https://doi.org/10.1016/j.neuro. 2005.05.004

Saalu, L. C.; Oyewopo, A. O.; Enye, L. A.; Ogunlade, B.; Akunna, G. G.; Bello, J.; Ogunmodede, O.S. The hepato-rejuvinative and hepato-toxic capabilities of Citrus paradisi Macfad fruit juice in Rattus norvegicus. African Journal of Pharmacy and Pharmacology, v. 6 , no. 14, p. 10561063, 2012. https://doi.org/10.5897/ AJPP12.095

Saira, K.; Zafar, U. Z.; Habib ur, R. A.; Rehana, K. Physiological and biochemical basis of salt tolerance in Ocimum basilicum L. Journal of Medicinal Plants and Studies, v. 2, p. 18-27, 2014.

Sanda, K.; Koba, K.; Nambo, P.; Gaset, A. Chemical investigation of Ocimum species growing in Togo. Flavour and Fragrant Journal, v. 13, p. 226-232, 1998. https://doi.org/10.1002/(SICI)10991026(1998070)13:4<226::AID-FFJ717 $>3.0 . \mathrm{CO} ; 2-\mathrm{H}$

Sharma, M. K.; Kumar, M.; Kumar, A. Ocimum sanctum aqueous leaf extract provides protection against mercury induced toxicity in swiss albino mice. Indian Journal of Experimental Biology, v. 40, p. 1079-1082, 2002.

Sharma, M. K.; Kumar, M.; Kumar, A. Study of mercury induced toxicity in liver and its modulation by Spirulina fusiformis and Ocimum sanctum. Cellular and Molecular Biology, v. 46, p. 227, 2000.
Stacey, N. H.; Kappus, H. Cellular toxicity and lipid peroxidation response to mercury. Toxicology and Applied Pharmacology, v. 63, p. 29-35, 1982. https://doi.org/ 10.1016/0041-008X(82)90023-0

Tan, S. W.; Meiller, J. C.; Mahaffey, K. R. The endocrine effects of mercury in humans and wildlife. Critical Reviews in Toxicology,

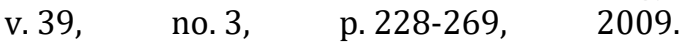
https://doi.org/10.1080/104084408022332 59

Trush, M. A.; Mimnaugh, E. G.; Gram, T.E. Activation of pharmacologic agents to radical intermediates: Implications for the role of free radicals in drug action and toxicity. Biochemical Pharmacology, v. 31, p. 33353346, 1982. https://doi.org/10.1016/00062952(82)90609-8

USEPA - US Environmental Protection Agency. Mercury in your environment. 2018. Available from: <http://www.epa.gov/hg/ effects.htm>. Accessed on: Sept. 21, 2018.

Valera, B.; Dewailly, E.; Poirier, P. Cardiac autonomic activity and blood pressure among Nunavik Inuit adults exposed to environmental mercury: A cross-sectional study. Environmental Health, v. 28, p. 924926, 2008. https://doi.org/10.1186/1476069X-7-29

Valey, H.; Gevenlock, A.; Bell, M. Practical clinical biochemistry. 15 . ed. London: William Heinemen Medical, 1980.

Vandenberghe, J. Hepatotoxicology: Mechanisms of liver toxicity and methodological aspects. Boca Raton: CRC Press, 1995.

Wang, J. S.; Huang, P. M.; Liaw, W. K. Kinetics of the desorption of mercury from selected fresh water sediment as influenced by mercury chloride. Water, Air, Soil Pollution, v. 12 , p. 533-542, 2007. https://doi.org/ 10.1007/BF00342297

WHO - World Health Organization. Elemental mercury and inorganic mercury compounds: Human health aspects. Geneva: WHO, 2003. (Concise International Chemical Assessment Document, CICAD 50).

Yannai, S.; Sachs, K. M. Absorption and accumulation of cadmium, lead and mercury from foods by rats. Food and Chemical 
Toxicology, v. 23, no. 31, p. 351-355, 1993.

https://doi.org/10.1016/0278-6915(93)

90190-A

Youcef, N.; Ahlem, B.; Sakina, Z. Amelioration of mercuric chloride toxicity on rat liver with argan oil and sodium selenite supplements. Internation Journal of Pharma and Bio Sciences, v. 4, no. 24, p. 839-849, 2013. 